УДК 902/904

https://doi.org/10.24852/2587-6112.2021.3.255.268

\title{
СВИНЦОВЫЕ СЛИТКИ И ИЗДЕЛИЯ ИЗ МАТЕРИАЛОВ САМОСДЕЛЬСКОГО ГОРОДИЩА
}

\author{
(С2021 г. Д.В. Васильев
}

Самосдельское городище в дельте Волги является археологическими остатками города Саксина. Частой находкой здесь являются слитки свинца - как отдельные, так и в виде кладов. Часть слитков имеют правильную геометрическую форму, часть имитируют какие-либо предметы, часть бесформенные, встречается также много обрезков слитков. Средневековый путешественник Абу Хамид ал-Гарнати, живший в Саксине, писал, что в торговле жители города используют олово. Вполне вероятно, что он имел в виду именно свинец, так как в средневековой алхимии свинец и олово были тождественны. На материале самого крупного клада свинцовых изделий из полуземлянки XII века общим весом 412,328 кг выделяются категории слитков. Прослежены некоторые соответствия распространённым на средневековом Востоке мерам веса. При этом приходится констатировать, что наблюдается большая весовая погрешность. Лишь небольшое число слитков попадают в определенные весовые нормы. Большая часть слитков клада имеет случайную форму. Лишь геометрически правильные слитки можно распределить по трём группам, которые в целом соответствуют весовым нормам ратля, манна и большого хорезмийского манна. Эти слитки можно условно считать обменными эквивалентами или гирями. Мелкие слитки могли служить средством обмена - «разменной монетой». Более точно весовое и стоимостное соответствие устанавливается для оригинальных изделий гривнообразного слитка, трапециевидных гирь.

Ключевые слова: археология, городище «Самосделка», город Саксин, средневековье, свинцовые слитки, денежно-весовые нормы, обменный эквивалент.

\section{LEAD INGOTS AND PRODUCTS MADE OF MATERIALS FROM SAMOSDELKA SETTLEMENT}

\section{V. Vasiliev}

Samosdelka settlement in the Volga delta is the archaeological remains of the city of Saqsin. Common finds for this area are lead ingots, both individual and in the form of hoards. Some of the ingots have a correct geometric shape, some imitate certain objects, while others are shapeless, and there are also many ingot pieces. The medieval traveller Abu Hamid al-Garnati, who lived in Saqsin, wrote that the inhabitants of the city used tin ingots in trade. It is likely that he actually meant lead, since in medieval alchemy, lead and tin are identical. The material of the largest hoard of lead products from a semi-dugout of the $12^{\text {th }}$ century with a total weight of $412.328 \mathrm{~kg}$ has allowed to identify individual categories of the ingots. A certain relationship has been traced with the measures of weight widespread in the medieval East. In this case, it should be stated that a large weight error is in place. Only a small number of ingots fall within certain weight standards. Most of the ingots in hoard treasure are randomly shaped. Only geometrically correct ingots can be subdivided into three groups, which generally correspond to the weight norms of ratl, mann and large Khorezmian mann. These ingots can be conventionally considered exchange equivalents or weights. Small ingots could serve as a means of exchange, or "fractional coins". The weight and cost correspondence has been established more precisely for original products - gryvna-shaped ingot, trapezoidal weights.

Keywords: archaeology, Samosdelka settlement, the city of Saqsin, the Middle Ages, lead ingots, weight and monetary standards, exchange equivalent.

Одной из самых частых находок среди материалов Самосдельского городища являются свинцовые предметы. Это как отдельные изделия: отливки разнообразной формы, свинцовые слитки, имитирующие альчики (бараньи астрагалы), свинцовые грузикипломбы, гирьки, так и бесформенные слитки и выплески. Культурный слой городища довольно сильно насыщен ими. Представля- ется даже целесообразным уточнить границы распространения культурного слоя городища методом металлодетекции свинца.

За годы исследования Самосдельского городища было найдено множество свинцовых изделий, как в культурных отложениях на раскопах, так и в виде подъёмного материала. Крупные клады свинца неоднократно были обнаружены на территории городища. Так, в 
самом начале исследований на памятнике, в 1990 году, крупный клад свинцовых слитков был обнаружен в урезе берегового обрыва в районе паромной переправы. Слитки свинца - свинцовые бесформенные выплески с завёрнутыми краями - были найдены среди обломков керамического хума. К сожалению, данный клад не был взвешен и включён в отчёт. Тем не менее один из авторов настоящей статьи видел эти предметы в момент находки. Большой клад весом около 70 кг был обнаружен на поверхности городища в 2006 году к северо-востоку от раскопа № 1 .

Целью данной работы является изучение свинцовых предметов, найденных на городище, и выявление их функционального назначения. Мы попытаемся выявить некоторые закономерности в распределении весовых норм свинцовых изделий, а также определить функциональное назначение этих предметов исходя из их веса и морфологии.

Прежде чем речь пойдёт собственно о свинцовых предметах, необходимо сказать, что авторы исследований на Самосдельском городище неоднократно обосновывали соотнесение его верхних и средних слоёв со средневековым торговым городом Саксином, располагавшимся в дельте Волги в XI-XIV вв. (Васильев, 2004, с. 264-269; Васильев, 2010, c. 338-339; Васильев, Гречкина, Зиливинская, 2003; Зиливинская, Васильев, Гречкина, 2006, с. 24-35; Васильев, Зиливинская, 2011, c. 156-164).

Наличие большого числа свинцовых предметов среди материалов Самосдельского городища обратило на себя внимание в связи со следующими сведениями, которые арабский странствующий правовед и писатель Абу Хамид ал-Гарнати приводит по отношению к городу Саксину (Саджсину): «...И отправился я по морю к стране хазар. И прибыл к огромной реке, которая больше Тигра во много-много раз, она будто море, из которого вытекают большие реки... На ней находится город, который называют Саджсин, в нем сорок племен гуззов, и у каждого племени отдельный эмир. У них большие дворы, а в каждом дворе - покрытый войлоками шатер, огромный, как большой купол, один вмещающий сто и больше человек. А в городе много купцов разных народностей и чужеземцев и арабов... У них имеет хождение олово (Курсив мой - Д.В.), каждые восемь багдадских маннов стоят динар, разрезают его на куски и покупают на него что хотят из фруктов, хлеба и мяса» (Ал-Гарнати, 2000, с. 98-99).
Ещё одно свидетельство об особенностях торговли в городе Саксине мы находим у Ибн-Русте: «...Жители этого города в торговле употребляли свинец (Курсив мой - Д.В.) вместо серебряной монеты, так что три багдадских «минна» свинца равнялись одному динару» (Известия ..., 1869, с. 64). Сведения весьма сходные с тем, что сообщает ал-Гарнати, разве что отличается оценочная стоимость динара - либо три минна или манна, либо восемь. Эта ошибка могла вполне произойти из-за схожести написания арабскими цифрами чисел «3» и «8». Весьма вероятно, что Ибн-Русте повторил слова ал-Гарнати.

В связи с тем, что в одном случае идёт речь об олове, а в другом - о свинце, необходимо сделать специальное пояснение. Долгое время свинец и олово называли одним именем «Плюмбум». Алхимики иногда считали олово видоизменением свинца и называли белым (Plumbum album) или блестящим (Plumbum candidum) свинцом в отличие от обыкновенного черного свинца (Plumbum nigrum). Впоследствии название «плюмбум» стали относить только к свинцу. А «белое олово» получило латинское название stannum, т. е. «стойкий». Эта же терминология была принята и в арабской алхимии, откуда перешла в Европу. Что касается русского «олово» и созвучных с ним литовского «alwas» и прусского «alwis», то представители индогерманской теории происхождения языков полагают, что эти названия произошли от латинского «album», фигурирующего в названии олова Plumbum album (Фигуровский, 1970, с. 50). Таким образом, сходство двух металлов позволяет нам говорить о том, что, скорее всего, мы имеем дело не с разными металлами, а с одним, и именно со свинцом. Хотя, конечно же, в эпоху Средневековья умели различать свинец и олово. Согласно традиционной металлопланетной алхимической символике, оловом управлял Юпитер, а свинцом - Сатурн (Василий Валентин, 2008, с. 410, 414).

В 2005 году на Самосдельском городище в ходе работ на раскопе № 1 была исследована полуземлянка, получившая название «сооружение № 23». В заполнении сооружения № 23 были найдены многочисленные фрагменты керамики, в основном красноглиняной гончарной, кости животных и рыб, рыбья чешуя. В заполнении также были найдены фрагменты железных цилиндрических замков с медной оковкой, железные стреловидные пластины - оковки деревянного ларца и большое количество мелких железных и свинцовых 
предметов. Сооружение № 23 представляло собой прямоугольную в плане полуземлянку размерами 3,6×2,4-2,8 м. Дно полуземлянки плоское, ровное, с некоторым уклоном к северо-западу. Глубина ямы составляла около 1 м. В нижней её части стенками сооружения являлись земляные стенки ямы. Вероятно, они были оштукатурены глиняным раствором. Такое предположение можно сделать исходя из того, что яма полуземлянки была выкопана в культурном слое и перерезала слой более раннего пожара, таким образом, если бы стенки не были оштукатурены, внутренние конструкции были бы всё время в саже и золе, чего не наблюдалось при расчистке ямы полуземлянки. Снаружи по углам сооружения № 23 были найдены столбовые ямы, являвшиеся, скорее всего, остатками наземных конструкций стен. Можно предположить, что в верхней части стенки сооружения 23 были фахверковыми, т. е. сырцовыми на деревянном каркасе. Вдоль всех четырех стенок ямы была сооружена земляная суфа полукольцевидной формы. Суфа была сделана довольно небрежно. В юго-восточном углу помещения в суфе была сооружена яма неправильной овальной формы размерами $80 \times 40$ см и глубиной около 1 м. Яма была наполнена свинцовыми слитками различной формы и размера. Слитки спеклись в единый ком, и между отдельными слитками совсем не было земли. Рядом с этим скоплением свинца лежали 8 крупных слитков пирамидальной и призматической форм. Еще одно скопление больших свинцовых слитков было найдено другой яме, расположенной у северной стены сооружения. Яма была заполнена крупными геометрически правильными свинцовыми слитками. Общий вес свинцовых слитков, обнаруженных в 2005 году, составлял около 289 кг.

В северо-восточном углу сооружения, на суфе располагались два каменных жернова, один на другом. Первоначально предполагалось, что это ручная мельница, но после их снятия в 2007 году выяснилось, что они прикрывают ещё одну яму, получившую номер 220. Яма имела овальную форму, размеры ее $94 \times 66$ см. Дно имеет два уровня и понижается в ЮВ части. Глубина ямы 30-35 см. Заполнением являлись свинцовые слитки общим весом 99,5 кг.

В ходе камеральной обработки при взвешивании клада была сделана попытка первичной систематизации слитков. Слитки были распределены по группам исходя из внешних признаков - размеров и формы. Среди найден- ных предметов были выделены следующие категории: большие геометрически правильные слитки в виде усечённой треугольной пирамиды (их общий вес составил 9,266 кг), большие геометрически правильные трапециевидные слитки (их общий вес - 10,210 кг), большие геометрически правильные слитки в форме многоугольников (общим весом 39,622 кг), большие геометрически правильные слитки в виде призм (их общий вес 17,430 кг), большие геометрически правильные слитки в виде треугольников (общим весом 3,642 кг), большие «лепёшки» - бесформенные плоские слитки (общий вес слитков в категории 52,417 кг), малые геометрически правильные слитки (их вес составляет 96,128 кг), малые «лепёшки» (общим весом 54,646 кг), бесформенные слитки (общий вес категории 101,141 кг). Многие слитки носили на себе следы разрубания топором, некоторые многие выплески-лепёшки имели подвёрнутые края. Видимо, края заворачивались с целью удобства дальнейшего использования слитков. Кроме описанных выше, выделяются следующие категории: свернутые свинцовые пластины; ромбовидные изделия; круглые слитки; конические отливки; пирамидальные изделия; грузики плоские круглые; грузики в форме круга с отверстием; грузила треугольные; многогранники; слитки полукруглые; прямоугольные слитки; слитки бесформенные с отверстием; слитки волютообразные; предметы неясного назначения, а также единственный в своём роде гривнообразный слиток в виде пластины вытянуторомбической формы, на поверхность которого нанесён точечный рисунок. Общий вес этих изделий составил 27,826 кг.

Общий вес свинцового всего клада из сооружения № 23 на Самосдельском городище составил 412,328 кг.

Довольно сложно поддаётся интерпретации общее назначение клада в целом. Он состоит из изделий разных категорий - здесь есть и явные гири определённых весовых норм, есть слитки, соответствующие мелким весовым нормам, есть изделия самого разного назначения, есть грузила. Возможно, это был склад сырья для дальнейшей переработки свинца в обменный эквивалент. В пользу этого говорит то обстоятельство, что две ямы из трех, в которых находился свинец, были скрыты. Одна - под двумя каменными жерновами, а другая - под обмазкой суфы. Таким образом, свинец хранился как ценность. На мысль о высокой стоимости 
свинца и на использование его в качестве обменного эквивалента наводят также упоминавшиеся выше свидетельства ал-Гарнати и Ибн-Русте.

Нами была выдвинута гипотеза, что веса слитков клада могут совпадать с мерами весов, использовавшимися на мусульманском Востоке.

В процессе камеральной обработки свинцовых находок в археологической лаборатории АГУ было проведено взвешивание каждого предмета. Данные о результатах взвешивания каждого отдельного слитка были занесены в составленную нами базу данных в виде электронной таблицы. Так как слой, в котором было обнаружено сооружение № 23, относится ко времени существования города Саксин (XI-XII вв.), были рассмотрены меры веса, использовавшиеся на территории ближайших областей, с которыми у города Саксина были установлены торговые отношения. Таковыми территориями являются Аравия, Ирак, Иран и входивший в зону культурного влияния Ирана Хорезм.

Из средневековых восточных письменных и археологических источников мы знаем о том, что меры веса монетные и товарные несколько отличались друг от друга. Дирхам золотой монетный, вычисленный с точность до миллиграмма по весу стеклянных гирь, относящихся к 780 г., равен 4,231-4,235 г (Хинц, 1968, с. 11). Он же равняется 1 мискалю. Серебряный дирхам равен 2,9645-2,82 г (Хинц, 1968, с. 12).

Дирхам ал-кайл (дирхам товарный, весовой) в Египте равнялся 3,125 г. Классический мискаль равняется 4,464 г, а практически египетский мискаль составлял 4,68 г (Хинц, 1968, с. 13).

В Ираке и Сирии канонический мискаль составлял 4,46 г. Дирхам в Ираке представлял собой каноническую величину в 3,125 г (Хинц, 1968, с. 15).

В Иране же вес мискаля следовал старой сасанидской мере веса и равнялся 4,3 г. В. Хинц в качестве среднего значения для иранского дирхама указывает величину в 3,2 г, отмечая, что в Иране весовые единицы были несколько выше средних (Хинц, 1968 , с. 16). В Хорезме вес мискаля равнялся 4,53-4,55 г. (Давидович, 1968, с. 94).

Манн - классическая мера веса, происходящая от греческой мины, равняется 2 ратлям по 130 дирхамов (Хинц, 1968, с. 25). Классический багдадский манн - 812,5 г. В Мекке он приравнивался к ратлю. Манн такого же веса использовался и в Египте. Сирийский манн - 819 г. Иракский манн имел два значения 812,5 г. (позднее Средневековье) и 803,56 г (раннее Средневековье) (Хинц, 1968, с. 26). Из множества иранских маннов, где эта единица веса была очень популярна, для нас актуальны два: малый манн весом в 832 г (применялся в Ширазе и Ахвазе) и средний манн - 1920 г. (применявшийся в Рее, Джурджане, Табаристане) (Хинц, 1968, с. 27). Все территории, располагающиеся восточнее (Хорезм, Индия, Афганистан), находятся в сфере влияния иранской торговли и метрической системы (Хинц, 1968, с. 28-34).

Ратль (происходит от римской литрьл) - наиболее употребительная мера веса на Востоке. В раннемусульманское время в Мекке ратль был равен 40 дирхамам, то есть равнялся 1,5 кг. Потом вес его снизился до веса 1 багдадского манна, то есть до 812,5 г. Он равняется 12 укийя (унциям) и является 1/100 частью кинтара (Хинц, 1968, с. 34). В Ираке багдадский ратль считался каноническим. Составлял он 130 дирхамов, что равняется 406,25 г (Хинц, 1968, с. 37). 1/20 часть ратля - истар (20,31), 1/12 часть ратля укийя $(33,85$ г). В Иране ратль всегда заменялся манном и в качестве самостоятельной меры веса не применялся. Хорезмийский ратль в XIV веке весил 1031,25 г. Точно такой же ратль известен и в Сарае на Волге в это же время (Хинц, 1968, с. 38).

Харвар (ослиный вьюк) - одна из наибольших весовых единиц, составляет 100 ратлей. Для Хорезма эпохи Средневековья он составлял 103,125 кг (Давидович, 1968, с. 101).

Итак, можно на основании этого обзора наиболее употребимых мер веса выбрать самые практичные, которые могут встретиться нам при весовой характеристике слитков из самосдельского свинцового клада. Очевидно, что не стоит брать в качестве сравнительных единиц меры веса монет, поскольку ограниченное хождение серебряной монеты в XI-XII вв. диктовало иные условия ведения торговли. В следующей таблице представлены эти единицы веса и их дробные доли, за исключением дирхама и мискаля как наиболее мелких единиц.

Для начала попробуем установить закономерности во всей выборке. Взвешивание свинцовых слитков проводилось нами с точностью до 2 граммов, поскольку точнее установить их вес было просто невозможно. Слитки (особенно небольшого размера) покрыты зачастую толстым слоем окислов, 
удаление которых значительно меняет их вес. В связи с этим оказалось невозможным определить десятые и сотые доли грамма, которые в значительной степени влияют на результат анализа. Кроме того, самые маленькие слитки, весом менее двух граммов, не были взвешены по отдельности из-за сильной коррозии. Они представляют собой бесформенные кусочки свинца - выплески, брызги. Оформленных изделий среди них нет.
Кроме того, по отношению ко всем слиткам можно отметить одну особенность - выполнены они весьма грубо, зачастую методом многослойного литья в форму, выполненную просто в земле. Таким образом, как нам представляется, говорить о весовых нормах данных слитков можно весьма приблизительно.

Малые веса - от двух до 200 граммов можно представить в виде двухграммовых диапазонов. Результаты взвешивания и коли-

Таблица 1. Количество слитков разных весов в кладе Table 1. Number of ingots with different weights in the hoard

\begin{tabular}{|c|c|c|c|c|c|c|c|c|c|c|}
\hline Вec, Г & 2 & 4 & 6 & 8 & 10 & 12 & 14 & 16 & 18 & 20 \\
\hline Кол-во & 44 & 140 & 99 & 160 & 152 & 117 & 135 & 115 & 183 & 78 \\
\hline Вec, Г & 22 & 24 & 26 & 28 & 30 & 32 & 34 & 36 & 38 & 40 \\
\hline Кол-во & 91 & 72 & 58 & 72 & 64 & 48 & 62 & 48 & 45 & 37 \\
\hline Вec, Г & 42 & 44 & 46 & 48 & 50 & 52 & 54 & 56 & 58 & 60 \\
\hline Кол-во & 32 & 32 & 24 & 37 & 23 & 27 & 25 & 23 & 23 & 29 \\
\hline Вec, Г & 62 & 64 & 66 & 68 & 70 & 72 & 74 & 76 & 78 & 80 \\
\hline Кол-во & 35 & 26 & 25 & 21 & 15 & 18 & 21 & 18 & 18 & 22 \\
\hline Вec, Г & 82 & 84 & 86 & 88 & 90 & 92 & 94 & 96 & 98 & 100 \\
\hline Кол-во & 24 & 11 & 11 & 10 & 18 & 18 & 14 & 14 & 6 & 9 \\
\hline Вec, Г & 102 & 104 & 106 & 108 & 110 & 112 & 114 & 116 & 118 & 120 \\
\hline Кол-во & 7 & 17 & 9 & 15 & 9 & 14 & 8 & 8 & 5 & 8 \\
\hline Вec, Г & 122 & 124 & 126 & 128 & 130 & 132 & 134 & 136 & 138 & 140 \\
\hline Кол-во & 13 & 3 & 10 & 9 & 7 & 7 & 10 & 4 & 9 & 5 \\
\hline Вec, Г & 142 & 144 & 146 & 148 & 152 & 154 & 156 & 158 & 160 & 162 \\
\hline Кол-во & 4 & 4 & 12 & 6 & 8 & 6 & 7 & 6 & 4 & 7 \\
\hline Вec, Г & 164 & 166 & 168 & 170 & 172 & 174 & 176 & 178 & 180 & 182 \\
\hline Кол-во & 6 & 4 & 3 & 8 & 2 & 5 & 6 & 8 & 3 & 1 \\
\hline Вec, Г & 184 & 186 & 190 & 192 & 194 & 196 & 198 & 200 & 202 & 204 \\
\hline Кол-во & 4 & 8 & 3 & 4 & 5 & 4 & 2 & 6 & 4 & 1 \\
\hline Вec, Г & 206 & 208 & 210 & 212 & 214 & 216 & 218 & 220 & 222 & 224 \\
\hline Кол-во & 6 & 2 & 4 & 3 & 1 & 2 & 1 & 3 & 2 & 2 \\
\hline Вec, $\Gamma$ & 226 & 230 & 234 & 236 & 238 & 240 & 242 & 244 & 246 & 248 \\
\hline Кол-во & 4 & 2 & 1 & 2 & 4 & 2 & 1 & 1 & 1 & 2 \\
\hline Вec, Г & 250 & 252 & 254 & 256 & 258 & 260 & 262 & 264 & 266 & 268 \\
\hline Кол-во & 1 & 3 & 3 & 2 & 2 & 4 & 5 & 2 & 2 & 2 \\
\hline Вec, Г & 270 & 272 & 274 & 276 & 280 & 282 & 286 & 288 & 290 & 292 \\
\hline Кол-во & 4 & 1 & 3 & 2 & 1 & 1 & 1 & 1 & 3 & 1 \\
\hline Bec, Г & 294 & 298 & 302 & 304 & 312 & 314 & 316 & 322 & 324 & 326 \\
\hline Кол-во & 2 & 1 & 2 & 2 & 1 & 1 & 2 & 1 & 2 & 1 \\
\hline Вec, Г & 328 & 330 & 332 & 336 & 338 & 342 & 344 & 346 & 348 & 350 \\
\hline Кол-во & 2 & 1 & 3 & 1 & 2 & 1 & 2 & 1 & 1 & 1 \\
\hline Вec, Г & 352 & 354 & 356 & 360 & 362 & 366 & 368 & 370 & 372 & 374 \\
\hline Кол-во & 3 & 1 & 1 & 2 & 1 & 1 & 1 & 1 & 2 & 1 \\
\hline Вec, Г & 376 & 378 & 384 & 386 & 388 & 390 & 392 & 394 & 396 & 398 \\
\hline Кол-во & 1 & 1 & 2 & 2 & 5 & 1 & 1 & 4 & 2 & 2 \\
\hline Вec, Г & 400 & 404 & 408 & 412 & 414 & 416 & 422 & 428 & 434 & 438 \\
\hline Кол-во & 2 & 1 & 2 & 1 & 3 & 1 & 2 & 2 & 1 & 2 \\
\hline Вec, Г & 442 & 454 & 460 & 476 & 480 & 484 & 490 & 496 & 506 & 518 \\
\hline Кол-во & 2 & 1 & 1 & 1 & 1 & 1 & 1 & 1 & 1 & 1 \\
\hline Вec, Г & 522 & 526 & 532 & 538 & 548 & 576 & 590 & 592 & 600 & 636 \\
\hline Кол-во & 1 & 1 & 1 & 1 & 1 & 2 & 1 & 1 & 1 & 1 \\
\hline Вec, Г & 644 & 652 & 662 & 664 & 674 & 682 & 690 & 702 & 710 & 722 \\
\hline
\end{tabular}




\begin{tabular}{|l|c|c|c|c|c|c|c|c|c|c|}
\hline Кол-во & 1 & 1 & 1 & 1 & 1 & 1 & 1 & 1 & 1 & 1 \\
\hline Вес, $\boldsymbol{\Gamma}$ & $\mathbf{7 2 6}$ & $\mathbf{7 3 6}$ & $\mathbf{7 4 6}$ & $\mathbf{7 5 2}$ & $\mathbf{7 5 6}$ & $\mathbf{7 6 2}$ & $\mathbf{7 7 0}$ & $\mathbf{7 7 2}$ & $\mathbf{7 8 2}$ & $\mathbf{8 0 2}$ \\
\hline Кол-во & 1 & 1 & 1 & 1 & 1 & 1 & 1 & 2 & 1 & 1 \\
\hline Вес, $\boldsymbol{\Gamma}$ & $\mathbf{8 0 8}$ & $\mathbf{8 1 2}$ & $\mathbf{8 1 8}$ & $\mathbf{8 2 0}$ & $\mathbf{8 3 0}$ & $\mathbf{8 6 4}$ & $\mathbf{9 2 6}$ & $\mathbf{9 3 8}$ & $\mathbf{9 9 0}$ & $\mathbf{9 9 6}$ \\
\hline Кол-во & 1 & 1 & 1 & 1 & 1 & 1 & 1 & 1 & 1 & 1 \\
\hline Вес, $\boldsymbol{\Gamma}$ & $\mathbf{1 1 3 0}$ & $\mathbf{1 1 3 2}$ & $\mathbf{1 1 3 6}$ & $\mathbf{1 1 5 6}$ & $\mathbf{1 1 7 2}$ & $\mathbf{1 1 8 8}$ & $\mathbf{1 2 0 8}$ & $\mathbf{1 2 2 2}$ & $\mathbf{1 3 3 6}$ & $\mathbf{1 4 2 4}$ \\
\hline Кол-во & 1 & 2 & 2 & 1 & 1 & 1 & 1 & 1 & 1 & 1 \\
\hline Вес, $\boldsymbol{\Gamma}$ & $\mathbf{1 4 8 2}$ & $\mathbf{1 5 2 6}$ & $\mathbf{1 5 5 2}$ & $\mathbf{1 6 3 6}$ & $\mathbf{1 6 5 4}$ & $\mathbf{2 7 2 5}$ & $\mathbf{2 8 6 4}$ & & & \\
\hline Кол-во & 1 & 1 & 1 & 1 & 1 & 1 & 1 & & & \\
\hline
\end{tabular}

чество слитков каждого веса приведены в таблице:

Как видно из таблицы № 1, количественной зависимости между какими-либо весовыми нормами и количеством слитков не наблюдается, несмотря на то, что можно было бы ожидать «всплески» количества, группирующиеся вокруг популярных на средневековом Востоке единиц веса.

Единственная зависимость тем не менее имеется - с увеличением веса слитков уменьшается их количество. Наибольшее число слитков выпадает на малые весовые значение. Наименьшее число - на крупные слитки.

Таким образом, мы можем констатировать, что самосдельский клад свинцовых изделий представляет собой случайный набор слитков, основной вес которых приходится на крупные - свыше 100 граммов.

Попробуем охарактеризовать клад в целом и отдельные выделенные нами при взвешивании группы слитков с помощью стандартных показателей описательной статистики Среднее значение веса слитка в кладе -

Таблица 2. Описательно-статистическая характеристика клада

Table 2. Descriptive and statistical characteristics of the hoard

\begin{tabular}{|l|c|c|c|c|c|c|}
\hline & Кол-во & Макс. & Мин. & $\begin{array}{c}\text { Среднее } \\
\text { знач. }\end{array}$ & $\begin{array}{c}\text { Среднее } \\
\text { квадратич. } \\
\text { отклонение }\end{array}$ \\
\hline $\begin{array}{l}\text { БГПФ*. Усеченная } \\
\text { треугольная пирамида }\end{array}$ & $\mathbf{9}$ & 2864 & 174 & 921,556 & & 571,7530864 \\
\hline БГПФ. Трапеции & $\mathbf{1 4}$ & 1636 & 304 & 729,2857 & 1132 & 354,3265306 \\
\hline БГПФ. Многоугольники & $\mathbf{4 2}$ & 1428 & 158 & 625,3333 & 328 & 276,5079365 \\
\hline БГПФ. Призмы & $\mathbf{2 7}$ & 1208 & 158 & 640,963 & & 227,297668 \\
\hline БГПФ. Треугольники & $\mathbf{6}$ & 772 & 322 & 534 & & 165,3333333 \\
\hline МГПФ** & $\mathbf{8 5 5}$ & 442 & 8 & 89,40117 & 22 & 57,27542013 \\
\hline Большие лепешки & $\mathbf{2 0 8}$ & 2725 & 34 & 232,1683 & 122 & 125,0951368 \\
\hline Маленькие лепешки & $\mathbf{1 7 8 6}$ & 192 & 2 & 25,92721 & 8 & 18,50949967 \\
\hline Все & $\mathbf{2 9 4 7}$ & 2864 & 2 & 80,18765 & 8 & 80,68893283 \\
\hline
\end{tabular}

*БГПФ - Большие геометрически правильные слитки

**МГПФ - Малые геометрически правильные слитки

80,197765 г - близко к значению $1 / 10$ доли багдадского манна весом в 812,5 г. Однако, скорее всего, это совпадение - слишком уж велико значение среднего квадратического отклонения в целом по всему кладу - 80,68893283 г. Мода составляет 8 г (сотая часть манна иракского или багдадского, или примерно два мискаля).

Наибольшее количество слитков (1786) приходится на категорию «Малые лепёшки» - бесформенные слитки небольших размеров. Настораживает, что веса в данной категории колеблются от 2 до 192 г. Видимо, категорию эту следует дробить на более гомоморф- ные группы. Среднее значение веса слитка в группе составляет 25,92721 г, которое при показателе вариативности (среднего квадратического отклонения) в 18,50949967 г может колебаться в диапазоне от 44,5 г до 7,43, то есть от одной сотой манна (или примерно от 2 мискалей) до десяти мискалей. Мода в данном случае также составляет 8 г.

В категории «Большие лепёшки», где также очень велик разброс весов, среднее значение веса равняется 232,1683 г, что примерно соответствует, учитывая большое среднее квадратическое отклонение, $1 / 4$ манна или хорезмийского ратля. 
В категорию «Малые геометрически правильные слитки» вошло 855 слитков - это вторая по численности слитков категория. Среднее значение в данной категории - 89,40117, что примерно соответствует $1 / 10$ части манна (с учётом среднего квадратического отклонения).

Категория «Большие геометрически правильные слитки - треугольники» представлена 6 предметами. Средняя величина веса слитка составляет 534 грамма, среднее квадратическое отклонение - 165,3333 г. Это укладывается в весовую норму половины манна.

Категория «Большие геометрически правильные слитки - призмы» состоит из 27 слитков. Среднее значение веса 640,963 г, среднее квадратическое отклонение 227,298 г. Веса этой категории также можно условно приравнять к половине манна или хорезмийского ратля.

Категория «Большие геометрически правильные слитки - многоугольники» представлена 42 слитками. Весовые соотношения весьма схожи с вышеописанной категорией - среднее значение веса слитка составляет 625,333 г, среднее квадратическое отклонение - 276,5079 г. Как и в предыдущем случае, мы можем условно приравнять веса слитков этой категории к половине манна или хорезмийского ратля. Между тем в этой и предшествующей категории веса колеблются в диапазоне от одной шестой манна до двух маннов (с учётом погрешности).

Категория «Большие геометрически правильные слитки - трапеции» включает в себя 14 слитков. Средний вес составляет 729,2857 г, что приближается по значению к манну. При этом среднее квадратическое отклонение составляет 354,326 г. Реальный вес слитков варьируется от 304 до 1646 г, то есть от половины манна до двух маннов (с учётом погрешности).

Категория «Большие геометрически правильные слитки - усечённые треугольные пирамиды» включает в себя 9 слитков. Средний вес слитка в категории составляет 921,556 г, что является условной величиной - здесь это наиболее ярко и наглядно видно, так как разброс реальных весов слитков очень велик - от 174 г до 2864 г.

Итак, несмотря на то, что ряд средних показателей в группах совпадает иногда с восточными мерами веса, мы можем сказать, что группы выделены условно, так как не прослеживается зависимость между весо- выми нормами и формой слитков. Исходя из данных таблицы № 3, можно сказать следующее: разрыв минимальных и максимальных значений в каждой группе очень велик. Величина и геометрически правильная форма слитка - это, как выясняется, не определяющий показатель. Или за геометрической формой слитков скрывается какая-то иная зависимость, не весовая. Веса разных групп в значительной мере дублируют друг друга.

Попробуем поработать с имеющимися группами иным способом. Объединим все большие геометрически правильные слитки в одну группу, сохраним группу малых геометрически правильных слитков и объединим малые и большие «лепёшки» также в одну группу. Итого у нас получится три группы слитков. Для того, чтобы показатели стали наглядными, мы будем строить гистограммы распределения веса слитков в группах.

Начнём с группы «Большие геометрически правильные слитки». В группу входит 98 слитков. Вес слитков в группе 65278 г. Разобьём веса слитков в группе на искусственные диапазоны по 100 граммов и подсчитаем количество слитков в каждом диапазоне. Это позволит несколько усреднить вес слитка и в то же время определить, какие весовые нормы внутри группы являются определяющими. Результат отобразим на гистограмме (рис. 1).

Гистограмма имеет три пика и в целом смещена влево. Один слиток весом в диапазоне от 2800 г до 2899 г (а точнее - 2864 г) стоит отдельно, что явственно указывает на его искусственное включение в данную группу. Он приближается по весу к большому иранскому (тебризскому) манну весом ровно в 3000 г, который введён в обращение с середины XIV века (Хинц, 1968, с. 27), или трём маннам.

Три пика соответствуют весам 300-399 г (к нему примыкает пик, соответствующий весовому диапазону в 400-499 г), 700-799 г (слева к нему примыкает пик средней высоты, соответствующий диапазону 600-699 г, а справа - пик, соответствующий диапазону 800-899 г, а также средней высоты пик 900-999 г), 1100-1199 г. Устойчивое попадание весов слитков в эти промежутки мы игнорировать не можем. Наверняка здесь мы имеем дело с реально существовавшими устойчивыми весовыми единицами.

Первый пик на гистограмме соответствует весовому диапазону от 300 до 499 г, что можно в целом соотнести с весовой нормой ратля. 


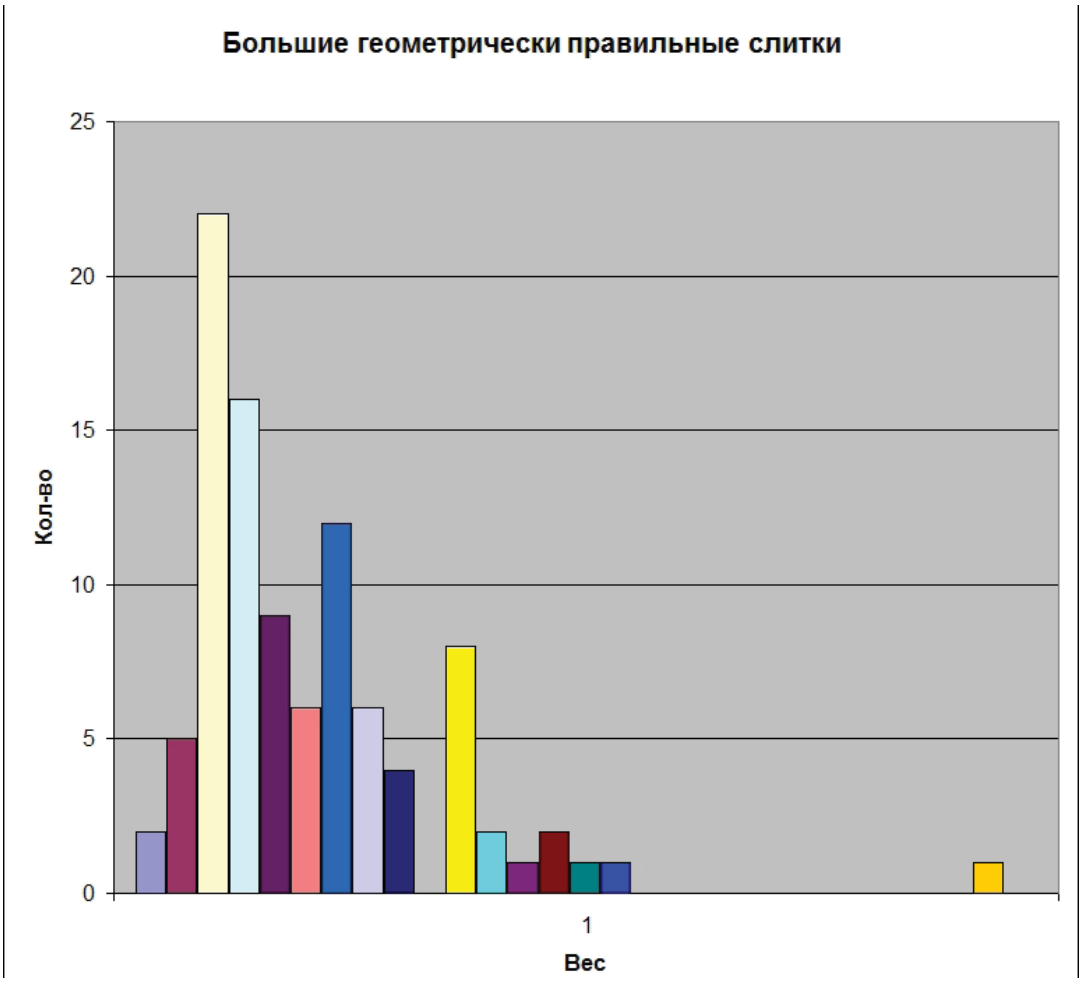

Рис. 1. Гистограмма распределения веса в группе «Большие геометрически правильные слитки»

Fig. 1. Histogram of weight distribution in the group "Large geometrically correct ingots"

Второй пик гистограммы соответствует весовому диапазону от 600 до 899 г, что условно можно соотнести с весовой нормой манна.

Третий пик гистограммы в диапазоне 1100-1199 г соответствует, на наш взгляд, большому хорезмийскому ратлю. Надо отметить здесь, что в Ургенче XIV в. один манн составлял 1188 г (Хинц, 1968, с. 32).

Теперь проведём такой же анализ группы «Малые геометрически правильные слит- ки». В группу входит 1786 слитков. Общий вес слитков данной группы составляет 46306 г. Поскольку веса слитков в данной группе значительно меньше, чем в вышеописанной, выстроим значения этих весов по возрастанию и разобьём на диапазоны по 4 г. Количество слитков, вошедших в каждый диапазон, подсчитаем и построим результирующую гистограмму (рис. 2).

Распределение весов малых геометрически правильных слитков

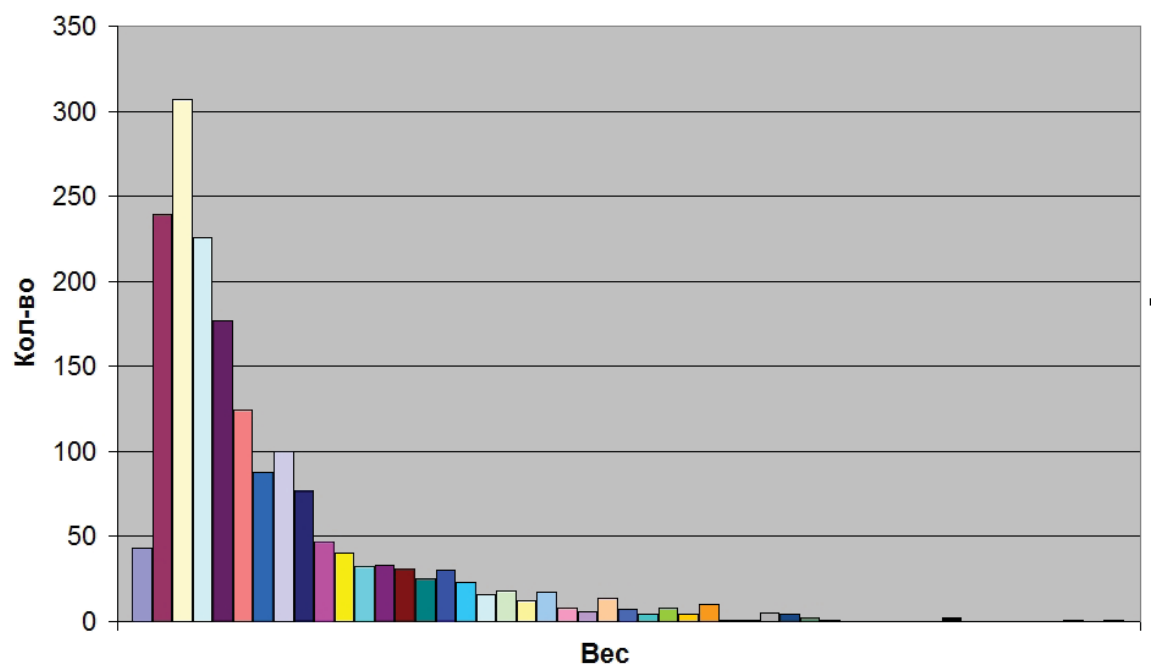

Рис. 2. Гистограмма распределения веса в группе «Малые геометрически правильные слитки» Fig. 2. Histogram of weight distribution in the group "Small geometrically correct ingots" 


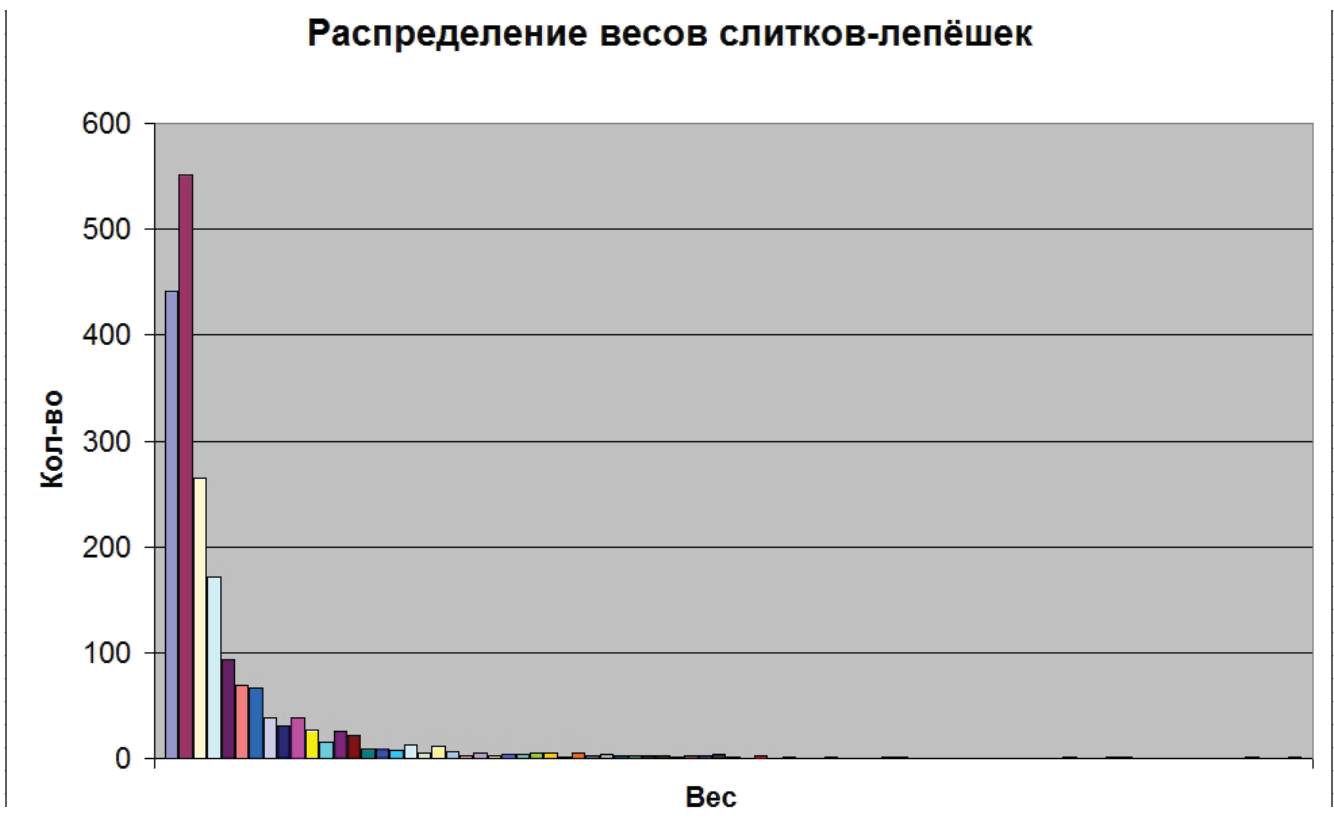

Рис. 3. Гистограмма распределения веса в группе «Слитки-лепёшки»

Fig. 3. Histogram of weight distribution in the "Ingots-pastilles" group

Гистограмма одновершинная, вершина смещена влево. Пик приходится на диапазон 8-11,9 г. Прилегающие к нему весовые диапазоны мы можем объединить - укрупнить диапазон, включив в него все четырёхграммовые диапазоны, в которые вошло более чем по 100 слитков. Получается один большой диапазон от 4 до 24 граммов, в который войдёт 1073 слитка из 1786, вошедших в данную группу, то есть более половины. Данный диапазон охватывает веса, соответствующие мискалю (4,3-4,55 г). В него же входят слитки весом в 2 мискаля, которые составляют наибольшее количество слитков в группе, а также слитки весом около 1 багдадского истара (20,31 г). Интересно отметить, что большое количество слитков (100 шт.) попадает в интервал от 28 до 32 г, что близко к весовому значению багдадской укии.

Слитки меньшего веса - от 2 до 4 г, которые соответствуют весу дирхама, относительно немногочисленны в данной группе.

Если объединить в одну группу все слитки-лепёшки, то получится довольно неоднородная группа бесформенных слитков весом от 2 г до 2725 г. Общее количество слитков составит 1994 шт., общий вес - 94597 г. Разобьём данную группу на весовые диапазоны по 10 г. Сразу оговоримся, что три самых крупных слитка весом 1526 г, 1654 г и 2725 г. выбиваются из группы, поскольку веса слитков в ней не нарастают постепенно до полутора - двух с половиной килограммов такая постепенность наблюдается в диапазоне от 2 г до 808 г. Далее следует значительная лакуна, завершают которую данные слитки. Вероятно, эти слитки должны были бы относиться к иной категории, если бы они имели геометрически правильную форму. Их веса приблизительно соответствуют большому и среднему иранским маннам.

Остальные слитки мы распределили по весовым диапазонам с шагом в 10 г. Такой размер диапазона обусловлен количеством слитков и разбросом их весов. В целом распределение количества слитков по весовым группам приведено на следующей гистограмме (рис. 3).

Пик её приходится на весовой диапазон от 10 до 19 граммов (551 слиток). В группу также входит большое число слитков весом от 0 до 9 граммов (442 шт.). В целом же наибольшее количество слитков (1430 шт.) приходится на диапазон от 0 до 39 г. Это вполне согласуется с распределением весов в группе малых геометрически правильных слитков.

Необходимо отметить, что общий вес всех слитков клада, который, как мы уже указывали, составляет 412,328 кг, почти точно соответствует 4 хорезмийским харварам. Вес одного харвара - 103,125 кг (Давидович, 1968, c. 105). Вполне вероятно, что это наблюдение окажется в будущем важным.

Ещё один вопрос необходимо прояснить в связи с предположением о том, что свинцовые слитки могли служить денежным эквивалентом для населения Самосдельского городища. В приведённой выше цитате из сочинения ал-Гарнати говорится, что каждые 8 багдадских маннов стоят динар (т. е. золотую моне- 


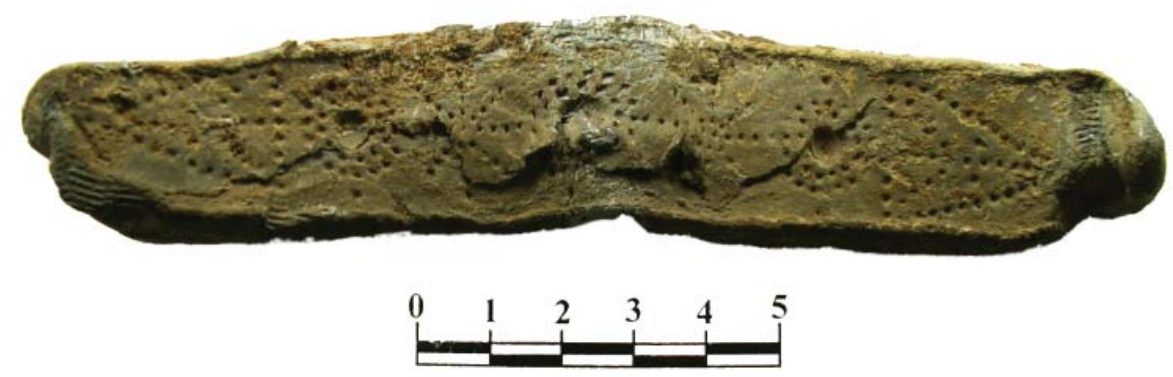

Рис. 4. Гривнообразный слиток с орнаментом

Fig. 4. Ornamental grivna-shaped ingot

ту). Один динар равнялся 15 дирхамам (монетам). Принимая во внимание всю условность этих построений, мы можем предположить, что 6500 граммов свинца (8 багдадских маннов по 812,5 г) равняются по стоимости одному динару. Таким образом, примерно 433,33 г свинца соответствуют одному серебряному дирхаму (монете). Общая стоимость клада из сооружения № 23 может примерно составлять 63,435 золотых динара, или 951,526 дирхамов, что представляет весьма значительную сумму.

Так, например, на один дирхам в X веке можно было купить 4 манна мяса, более 5 кг пшеницы, от 7 до 12 кг ячменя, около 40 кг фиников. Кувшин стоил 0,5 дирхама, метр полотна - 2 дирхама. Скромное существование супружеской четы в год обошлось бы в 300 дирхамов (Фёдоров, 1972, с. 73-81).

Стоимость слитков весом от 2 до 8 граммов, таким образом, могла быть вполне достаточной для осуществления обменных операций, и исходя из этого, они вполне могли служить эквивалентом мелкой разменной монеты.

Весьма интересными находками, которые были совершены как в раскопе, так и вне его, являются слитки правильной формы в виде прямоугольной в основании усечённой пирамиды. Эта форма, конечно же, лишь относительно правильная, насколько она может быть правильной при отливке в неровной земляной матрице методом многослойного литья (форма заполнялась расплавленным свинцом в несколько приёмов). Самый большой слиток, весом в 4164 г, был обнаружен в береговом урезе городища, где он был вымыт рекой из культурного слоя. Множество слитков - меньших размеров, но близких по форме - было обнаружено в культурных слоях XI-XII вв. Их веса колеблются в диапазонах, позволяющих предположить наличие десятикратной пропорции, соотносящейся с весом мискаля (около 4 г), и наличие кратных ему весовых норм - 10 мискалей (около 40 г) и 1000 мискалей (около 4000 г). (рис. 7) Вес самых малень- ких слитков в этой категории составляет 42 г и 4 г. Кроме того, вес большого слитка примерно равняется вычисленному нами свинцовому эквиваленту десяти серебряных дирхамов. Таким образом, слитки, кратные данному весу, также можно расценивать в качестве денежных и весовых эквивалентов.

В составе клада из сооружения № 23 встречаются трапециевидные слитки, которые также можно назвать гирями. Веса этих слитков - 658 г, 536 г, вес трёх небольших трапециевидных слитков - 76 г, 76 г и 70 г. Очевидно, что здесь мы наблюдаем иную весовую зависимость. Слиток в 658 граммов примерно соответствует весу трёх средних иранских маннов. Слиток в 436 г - примерному весу 4 средних иранских маннов или весу двух малых маннов. Слитки же весом 70-80 г приблизительно соответствуют 1/10 доле малого манна. С учётом грубости отливки (которая производилась в открытые, чаще всего земляные, формы, что видно по поверхности слитков) можно сказать, что предполагаемые гирьки или весовые слитки лишь очень приблизительно соответствуют весовым прототипам, наверняка высокой точности никто не стремился добиться - недостающие доли весовых норм можно было получить, подкладывая на весы срезки или обрубки с бесформенных слитков. Однако в таком случае в меновой торговле должны были применяться какието эталонные гири из того же свинца или из железа. Тем не менее они до сих пор не были найдены на городище.

Большой интерес вызывает слиток весом в 390 г, что приблизительно соответствует ратлю (около 400 г), или 0,9 серебряного дирхама по стоимости. Изделие представляет собой толстую пластину вытянуто-ромбической формы (рис. 4), которая расширяется к середине. Длина 15,5 см, ширина у одного края 2,7 см, у другого края - 2,3 см, ширина посередине -3 см, толщина пластины - около 1 см. Узкие концы закруглены и имеют выступающие 


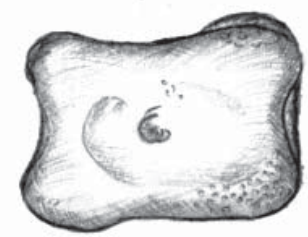

68 гр.

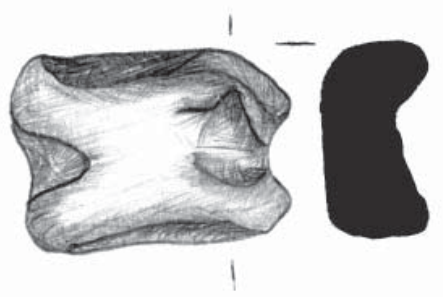

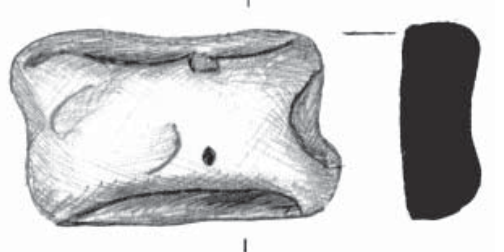

44 гр.
Рис. 5. Свинцовые слитки в виде бараньих альчиков

Fig. 5. Lead ingots

in the form of lamb astragal

Рис. 6. Свинцовые торговые пломбы

Fig. 6. Lead trade seals
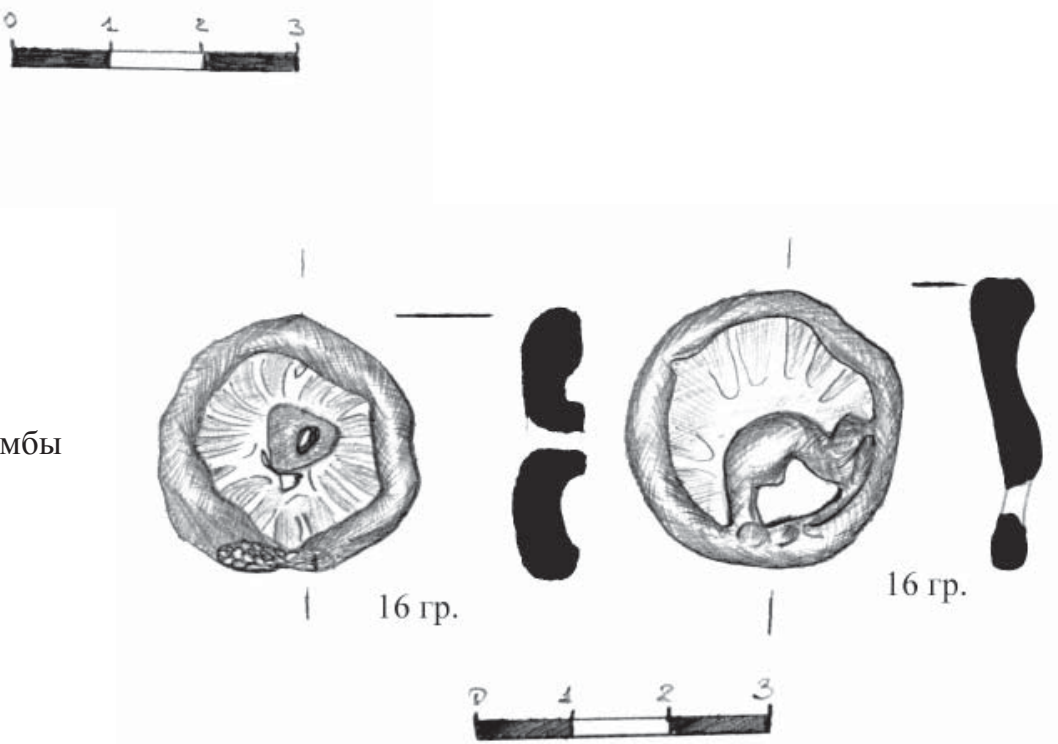

вверх края. На поверхность пластины нанесён орнамент точками-углублениями. По центру слитка располагается орнаментальный круг с углублением в центре, выполненный точками в виде двух концентрических окружностей. Два аналогичных круга располагаются справа и слева на некотором расстоянии от центрального. Между боковыми кругами и центральным нанесены орнаменты в виде четырёх пересекающихся прямых линий, образующих две пары пересекающихся крестов - прямых и косых. На концах пластины нанесены симметричные орнаменты в виде равнобедренных треугольников, обращённых острыми углами к концам слитка. Внутри треугольники разделены медианами. От углов основания к середине медианы проведены линии. Линиями, параллельными основанию, также отделяется верхняя треть треугольника. Данное изделие, безусловно, является оригинальным и не имеет аналогий. Мы можем лишь предполагать, что этот слиток, по форме близкий к ладьевидным гривнам или денежным слиткам-«сомам», имел такое же назначение.

Помимо этого, в составе клада были обнаружены 2 довольно грубые отливки в виде альчиков весом соответственно 68 и 44 г. (рис. 5), а также 2 грузика-пломбы, также выполненных грубо и небрежно, весом по 16 г каждая (рис. 6)
В 2011 году на поверхности городища у северо-западного угла раскопа № 2 был обнаружен крупный слиток свинца весом 15900 г. Он представляет собой полукруглую отливку, совершённую в неровную чашевидную яму, выкопанную в земле. Полукруглая форма и следы поперечного разрубания позволяют предположить, что это лишь половина круглого слитка весом около 32 кг. Практически полное соответствие веса слитка-половинки русскому пуду, а также тот факт, что он был обнаружен на поверхности городища, позволяют предположить, что данный слиток был отлит в русское время, когда на территории городища существовал рыбозавод. Тогда этот слиток мог использоваться, например, как гнёт при засолке рыбы. В то же время не исключено, что данный слиток представляет собой единицу веса в 20 маннов, соответственно, вес полного слитка составлял около 40 маннов.

Статистические наблюдения, проведённые нами, а также обзор свинцовых изделий позволяют сделать следующие предварительные выводы:

1. На материале клада свинцовых изделий из сооружения № 23 с раскопа № 1 прослеживаются некоторые приближённые соответствия части слитков распространённым на средневековом Востоке мерам веса. 

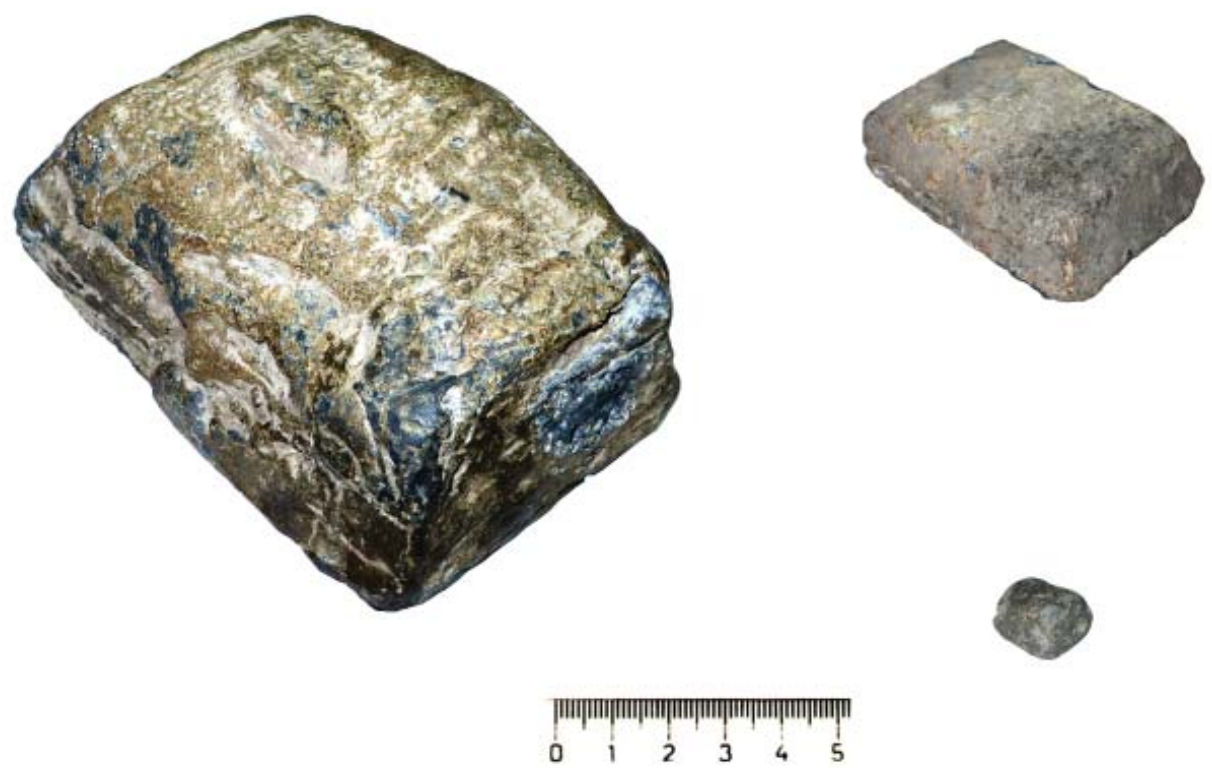

Рис. 7. Свинцовый трапецивидный слиток. Вес - 4164 г.

Fig. 7. Lead trapezoidal ingot. Weight $-4164 \mathrm{~g}$.

2. Подсчитать общее количество слитков, соответствующих тем или иным мерам веса, не представляется возможным из-за большой весовой погрешности и условности их отнесения к тем или иным весовым категориям.

3. Можно констатировать, что слитков, попадающих в определённые весовые нормы в составе клада, - меньшинство.

4. Большая часть слитков клада является случайными слитками - выплесками, отливками. Веса этих слитков распределяются в соответствии с закономерностью «чем больше вес слитков - тем меньше их количество».

5. Веса слитков не группируются вокруг значений весовых норм ни в одной группе, кроме группы больших геометрически правильных слитков, где прослежены три подгруппы изделий, которые в первом приближении соответствуют весовым нормам ратля, манна и большого хорезмийского манна.

6. Слитки из группы больших геометрически правильных можно, таким образом, условно считать обменными эквивалентами или гирями.

7. Мелкие слитки также могли служить средством обмена.

8. Весовое и стоимостное соответствие устанавливается для оригинальных изделий - гривнообразного слитка, трапециевидных гирь.

Причину появления большого количества свинцовых слитков на Самосдельском городище мы можем предположительно объяснить использованием их в виде обменного эквивалента (денег) в условиях «серебряного голода» вследствие экономического кризиса на Востоке и прекращения чеканки дирхемов
(Ильин, 1924, с. 3). Теперь считается установленным, что основными причинами серебряного кризиса на Востоке являлись: а) интенсивный отлив серебряных монет-дирхемов в предшествующее кризису время за пределы эмитента, главным образом в Восточную Европу, пропорционально чему происходило истощение запасов этого металла у его экспортеров (вывозимое серебро оседало там и больше не возвращалось обратно: к этому времени относится множество монетных кладов, порою очень внушительных, обнаруживаемых на территории России, Скандинавии, западноевропейских стран); б) диаметрально противоположно этому усиливалась нужда в средствах обращения на внутреннем рынке Халифата в связи с бурным ростом городов, расширением товарного производства и торговли - всё это настойчиво требовало увеличения количества денег в обращении (Раджабли, 1997, с. 42). В этот период наблюдается порча монеты - уменьшение доли серебра в сплаве вплоть до полного его исчезновения и замены медью.

Видимо, свинцовые слитки Самосдельского городища, призванные обсуживать нужды внутреннего саксинского рынка, были адекватным ответом на нехватку драгоценных металлов и монет из них. Если принять во внимание количество слитков, обнаруженных на Самосдельском городище, и предположить, что большая часть этих слитков служила заменой серебряным монетам, то мы можем утверждать, что внутренний обмен на рынках города Саксина имел значительную интенсивность. 


\section{ЛИТЕРАТУРА}

Василий Валентин. Алхимические трактаты / Пер. В. фон Эрцен-Глерона. Киев: Автограф, 2008. $592 \mathrm{c}$.

Васильев Д.В. О местоположении города Саксин // Проблемы археологии Нижнего Поволжья. I Международная Нижневолжская археологическая конференция (г. Волгоград, 1-5 ноября 2004 г.). Волгоград : ВолГУ, 2004. С. 264-269.

Васильев Д.В. Результаты изучения слоёв золотоордынского времени на Самосдельском городище в дельте Волги (по материалам раскопа №2) // XVIII Уральское археологическое совещание: культурные области, археологические культуры, хронология: Материалы XVIII Уральского археологического совещания / Науч. ред. Г.Т. Обыденнова и др. Уфа: БГПУ, 2010. С. 338-339.

Васильев Д.В., Гречкина Т.Ю., Зиливинская Э.Д. Городище Самосделка - памятник домонгольского периода в низовьях Волги // Степи Европы в эпоху средневековья. Т. 3. Половецко-золотоордынское время / Гл. ред. А.В. Евглевский. Донецк: ДонНУ, 2003. С. 83-122.

Васильев Д.В., Зиливинская Э.Д. К вопросу об интерпретации Самосдельского городища на разных этапах его существования // Самосдельское городище: вопросы изучения и интерпретации / Отв.ред. Д. В. Васильев. Астрахань: Издатель: Сорокин Роман Васильевич, 2011. С. 156-164.

Давидович E.A. Материалы по метрологии средневековой Средней Азии. // Хинц В. Мусульманские меры и веса с переводом в метрическую систему. Давидович Е.А. Материалы по метрологии средневековой Средней Азии. М.: Наука, 1970. С. 79-122, 132-143.

Зиливинская Э.Д., Васильев Д.В., Гречкина Т.Ю. Раскопки на городище Самосделка в Астраханской области в 2000-2004 гг. // РА. 2006. № 4. С. 24-35.

Из глубины столетий / Сост., вступительные статьи и комментарии Б.Л. Хамидуллин. Казань: Татар. кн. изд-во, 2000. $271 \mathrm{c.}$

Хвольсон Д.А. Известия о хозарах, буртасах, болгарах, мадьярах, славянах и руссах Абу-Али Ахмеда бен Омар Ибн-Даста, неизвестного доселе арабского писателя начала X века, по рукописи Британского музея. СПб.: Тип. Импер. акад. наук, 1869. 199 с.

Ильин А.А. Топография кладов древних русских монет X-XI вв. и монет удельного периода. Л.: Российская государственная академическая типография, 1924. 63 с.

Раджабли А. Нумизматика Азербайджана. (Очерки истории монетного дела и денежного обращения Азербайджана). Баку: Элм ве Хаят, 1997. 232 с.

Федоров М.Н. Еще о покупательной способности дирхема и динара в Средней Азии и сопредельных с нею странах в IX-XII вв. // СА. 1972. №2. С. 73-81.

Фигуровский Н.А. Открытие элементов и происхождение их названий. М: Наука, 1970. 207 с.

Хини В. Мусульманские меры и веса с переводом в метрическую систему. // Хинц В. Мусульманские меры и веса с переводом в метрическую систему. Давидович Е.А. Материалы по метрологии средневековой Средней Азии. М.: Наука, 1968. С. 9-78, 132-143.

\section{Информация об авторе:}

Васильев Дмитрий Викторович, кандидат исторических наук, Руководитель Школы «Археология Нижнего Поволжья», Астраханский государственный университет (г. Астрахань, Россия); hvdv@mail.ru

\section{REFERENCES}

Vasiliy Valentin. 2008. Alkhimicheskie traktaty (Alchemical Treatises). Kiev: “Avtograf” Publ. (in Russian).

Vasiliev, D. V. 2004. In Problemy arkheologii Nizhnego Polozh 'ia (Issue of the Archaeology of the Lower Volga Region). Volgograd: Volgograd State University, 264-269 (in Russian).

Vasiliev, D. V. 2010. In Obydennova, G. T. et al. (eds.). XVIII Ural'skoe arkheologicheskoe soveshchanie: kul'turnye oblasti, arkheologicheskie kul'tury, khronologiia (18 ${ }^{\text {th }}$ Ural Archaeological Conference: Cultural Areas, Archaeological Culture, Chronology). Ufa: Bashkir State Pedagogical University, 338-339. (in Russian).

Vasiliev, D. V., Grechkina, T. Yu., Zilivinskaya, E. D. 2003. In Evglevskii, A. V. (ed.-in-chief). Stepi Evropy $v$ epokhu srednevekov'ia (Steppes of Europe in the Middle Ages) 3. Polovetsko-zolotoordynskoe vremia (The Cuman-Golden Horde Period). Donetsk: Donetsk National University, 83-122 (in Russian).

Vasiliev, D. V., Zilivinskaya, E. D. 2011. In Vasiliev, D. V. (ed.). Samosdel'skoe gorodishche: voprosy izucheniia i interpretatsii (Samosdelka Settlement: Issues of Study and Interpretation). Astrakhan: "Sorokin R.V." Publ., 156-164 (in Russian).

Davidovich, E. A. 1970. In Hinz, W. Musul'manskie mery i vesa s perevodom v metricheskuiu sistemu (Muslim Weights and Measures with Conversion to the Metric System). Davidovich, E. A. Materialy po 
metrologii srednevekovoi Srednei Azii (Materials on the Metrology of Medieval Central Asia). Moscow: "Nauka" Publ., 79-122, 132-143 (in Russian).

Zilivisnkaya, E. D., Vasiliev, D. V., Grechkina, T. Yu. 2006. In Rossiiskaia Arkheologiia (Russian Archaeology) (4), 24-35 (in Russian).

Khamidullin, B. L. (ed.). 2000. Iz glubiny stoletii (From the Depths of Centuries). Kazan: "Tatarskoe knizhnoe izdatel'stvo" Publ. (in Russian).

Khvol'son, D. A. 1869. Izvestiia o Khazarakh, Burtasakh, Bolgarakh, Mad'iarakh, Slavianakh i Russakh Abu Ali Akhmeda Ben Omar Ibn-Dasta, neizvestnogo dosele arabskogo pisatelia nachala X veka, po rukopisi Britanskogo muzeia (News of the Khazar, Burtas, Bulgar, Magyar, Slavs and Russ by Abu Ali Ahmed ben Omar ibn Dasta, Hitherto Unknown Arabic Writer of the Beginning of the $10^{\text {th }}$ Century, the Manuscript of the British Museum for the First Time Published). Saint Petersburg: Typography of the Imperial Academy of Sciences (in Russian).

Il'in, A. A. 1924. Topografia kladov drevnikh russkikh monet X-XI vv. i monet udel'nogo perioda (Topography of the 10 $10^{\text {th }}-11^{\text {th }}$ Century Hoards of Ancient Russian Coins and the Coins of the Period of Independent Principalities). Leningrad (in Russian).

Radzhabli, A. 1997. Numiznatika Azerbaidzhana (Ocherki istorii monetnogo dela i denezhnogo obrashcheniia Azerbaidzhana) (Numismatics of Azerbaijan. (Essays on the History of Coinage and Monetary Circulation of Azerbaijan). Baku: "Elm veKhaiat" Publ. (in Russian).

Fedorov, M. N. 1972. In Sovetskaia Arkheologiia (Soviet Archaeology) (2), $73-81$ (in Russian).

Figurovsky, N. A. 1970. Otkrytie elementov i proiskhozhdenie ikh nazvanii (Discovery of Elements and the Origins of their Names). Moscow: "Nauka" Publ. (in Russian).

Hinz, W. 1970. In Hinz, W. Musul'manskie mery i vesa s perevodom v metricheskuiu sistemu (Muslim Weights and Measures with Conversion to the Metric System). Davidovich, E. A. Materialy po metrologii srednevekovoi Srednei Azii (Materials on the Metrology of Medieval Central Asia). Moscow: "Nauka" Publ., 9-78, 132-143 (in Russian).

\section{About the Author:}

Vasiliev Dmitry V. Candidate of Historical Sciences. Astrakhan State University. Tatischev St., 20a, Astrakhan, 414056, Russian Federation;.hvdv@mail.ru 